\title{
Pendampingan Santri Pesantren Fatahillah dalam Mendorong Kesadaran Shalat Berjamaah
}

\author{
Nurlaela, Usep Setiawan \\ Program studi Pendidikan Agama Islam, STAI DR. KH. EZ. Muttaqien Purwakarta \\ e-mail: nurlaela091298@gmail.com, usepsetiawan83@gmail.com
}

DOI: https://doi.org/10.52593/svs.01.1.03 Naskah diterima: 19 Desember 2020, direvisi: 22 Desember 2020, disetujui: 11 Januari 2021

\section{Abstraksi}

Kata Kunci:

Santri, Shalat

Berjamaah,

Kesadaran

\begin{abstract}
Kegiatan pengabdian ini dilatarbelakangi karena telah terjadi penurunan kesadaran santri dalam pelaksanaan sholat berjamaah di Pondok Pesantren Fatahillah. Berdasarkan hal tersebut, kegiatan ini bertujuan untuk mengetahui penyebab penurunan dan peningkatan kesadaran santri terhadap pelaksanaan shalat berjamaah. Hasil dari kegiatan ini diperoleh bahwa sosialisasi yang diadakan terhadap santri mampu mendorong kesadaran tentang pentingnya sholat berjamaah dengan treatment kedisiplinan kegiatan pondok di pondok pesantren Fatahillah.
\end{abstract}

\section{PENDAHULUAN}

Pesantren, kerap diartikan sebagai asrama tempat santri atau tempat murid-murid belajar mengaji dan sebagainya ( KBBI, 2005:866). Dalam komunitas pesantren ada santri, ada kiai, ada tradisi pengajian serta tradsi lainnya, ada pula bangunan yang dijadikan para santri untuk melaksanakan semua kegiatan selama 24 jam. Saat tidurpun para santri menghabiskan waktunya di asrama pesantren. Adapun kata santri sendiri berasal dari kata cantrik, yang berarti murid dari seorang resi yang biasanya juga menetap dalam satu tempat yang dinamakan dengan padepokan. Pesantren mempunyai persamaan dengan padepokan dalam beberapa hal, yakni adanya murid ( cantrik dan santri), adanya guru (kiai dan resi), adanya bangunan ( pesantren dan padepokan), dan terakhir adanya kegiatan belajar mengajar (Fuad \& Suwito NS,2009:28).

Ibadah merupakan rangkaian ritual yang dilakukan manusia dalam rangka pengabdian atau kepatuhan kepada sang pencipta. Ibadah dalam islam tidak hanya terbatas pada hubungan manusia dengan Allah semata, melainkan juga terdapat hubungan antara manusia dengan manusia lainnya serta manusia dengan alam (Razak, 1993: 18). Ada dua pembagian ibadah dalam islam, yaitu ibadah mahdhah dan ghairu mahdhah. Ibadah mahdhah, yaitu ibadah yang berhubungan dengan penjalanan syariat Islam yang terkandung dalam rukun Islam. Contoh ibadah mahdhah antara lain sholat, zakat, puasa dan haji. Sementara ibadah ghairu mahdhah adalah ibadah yang dilaksanakan umat islam dalam hubungannya denagan sesama manuasia dan lingkungannya. Ibadah ghairu mahdhah dikenal dengan ibadah muamalah (Nata, 2002:55).

Dari dua pembagian ibadah ini, secara implisit maupun eksplisit ibadah tidak hanya berupa rangkaian ucapan dan gerakan semata. Lebih dari itu dibalik ibadah terdapat nilai-nilai luhur yang mengatur hubungan antar sesama. Nilai-nilai luhur ini biasa dikenal sebagai etika atau akhlak. Hal ini yang kemudian dijadikan sebagai pijakan bagi umat islam untuk dapat menjadikan kehidupannya menjadi baik dan selalu bermanfaat bagi diri dan lingkungannya. 
Terkait manifestasi etika atau akhlak tersebut, di dalam islam keberadaannya perlu diaktualisasikan dalam kehidupan sehari-hari. Adapun wujudnya adalah 1). Akhlak kepada Allah SWT, 2). Akhlak terhadap diri sendiri dan 3). Akhlak terhadap orang lain (zain dkk, 2005:xvii). Pembagian akhlak ini yang kemudian disebut sebagai nilai-nilai luhur yang penting untuk dikembangkan bagi setiap muslim.

Berangkat dari ilustrasi ini jelas bahwa ibadah mempunyai nilai bagi ynag menjalankannya. Selain nilai dari sebuah ibadah, keberdaannya juga mempunyai tujuan yang telah ditetapkan. Perintah ibadah ini terkandung dalam filosufi tujuan penciptaan manusia yang terkandung dalam Qur'an. Adz Dzariyat : 56.

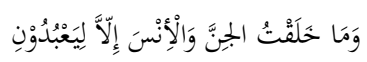

Artinya: "Dan aku tidak menciptakan jin dan manusia melainkan supaya mereka mengabdi kepada-Ku (QS. Adz Dzariyat : 56). “

Maksud ayat tersebut adalah Allah menciptakan manusia dengan tujuan untuk menyuruh mereka beribadah kepada-Nya, bukan karena Allah butuh kepada mereka. Ayat tersebut dengan gamblang telah menjelaskan bahwa Allah SWT dengan menghidupkan manusia di dunia ini agar mengabdi atau beribadah kepada-Nya (supadie,2011: 184). berdasarkan penjelasan tersebut manusia membutuhkan "ibadah" untuk eksistensi dirinya.

Adapun seperti yang sudah di jelaskan diatas bahwasannya ibadah terbagi dua yaitu ibadah mahdhah dan ghariu mahdhah. Penulis disini akan mempokuskan pembahasan terhadap ibadah mahdhah dalam konteks solat berjama'ah. Oleh karena itu sangat penting bagi santri paham terhadap nilai penting ibadah sebagai penerus para tokoh agama. Kegiatan ini dilakukan oleh penulis di pondok pesantren fatahillah yang berlokasi di jalan terusan kapten Halim Blok sawah lega Desa pasawahan anyar Rt 08 Rw 11 kecamatan pasawahan kabupaten purwakarta jawa barat.

Penulis mengamati selama program kegiatan english course berlangsung di pondok pesantren fatahillah kurang lebih 200 santri yang menjadi peserta begitu bersemangat dan termotivasi dalam belajarnya karena moment ini juga merupakan kesempatan besar mereka, Namun dibalik semangatnya para santri dalam melaksanakan pembelajaran dan dikarnakan sedikitnya juga waktu istirahat menjadikan terhambatnya ibadah shalat berjamaah yang tadinya sudah terbiasa 5 waktu shalat wajib dilaksanakan dengan berjamaah, dikarnakan adanya faktor yang menghambat kini kesadaran dan pemahaman santri sedikit demi sedikit berkurang terhadap nilai pentingnya beribadah sholat berjamaah di waktu siang, oleh karena itu saya sebagai peneliti berusaha mencari solusi bagaimana agar santri terbiasa kembali melaksanakan sholat dengan berjamaah di waktu siang dan kegitan belajar mengajar berjalan dengan baik sehingga keduanya terjalankan tanpa ada penghambat apapun. Dengan itu penulis mengangkat judul "pemahaman santri terhadap nilai penting ibadah (study kasus shalat berjamaah di pondok pesantren fatahillah )".

Yang menjadi fokus dalam kegiatan ini, penulis diantaranya yaitu pertama, apa makna nilai penting shalat berjamaah. Kedua, mengapa terjadi penurunan kesadaran santri terhadap shalat berjamaah. Ketiga, Bagaimana cara dewan santri ponpes fatahillah guna meningkatkan kesadaran santri terhadap sholat berjamaah. Dengan adanya permasalahan tersebut maka tujuan kegiatan ini yaitu pertama, Untuk mengetahui apa makna nilai penting shalat berjamaah. Kedua, Untuk mengetahui penyebab penurunan kesadaran santri terhadap shalat 
berjamaah. Ketiga, Untuk meningkatkan kesadaran santri terhadap pentingnya shalat berjamaah di ponpes fatahillah.

Salah satu tolok ukur keberhasilan belajar mengajar adalah apabila suatu konsep ilmu pengetahuan sudah di fahami oleh para siswa. (KBBI, Poerwadarmita, 1984) pemahaman diartikan mengerti benar. Jadi seseorang dikatakan faham terhadap sesuatu bila orang tersebut mampu menjelaskan hal tersebut. Pengertian pemahaman menurut Bloom (Hadi, 2003) Adalah kemampuan menangkap pengertian-pengertian seperti mampu mengungkapkan suatu materi yang disajikan kedalam bentuk yang dapat dipahami, mampu memberikan interprestasi dan mampu mengklasifikasikannya.

Shalat menurut bahasa adalah doa. ${ }^{1}$ Dengan kata lain mempunyai arti mengagungkan. Shalla-yushallu-shalatan adalah akar kata shalat yang berasal dari bahasa Arab yang berarti berdoa atau mendirikan shalat. Kata shalat, jamaknya adalah shalawat yang berarti menghadapkan segenap pikiran untuk bersujud, bersyukur, dan memohon bantuan. 2 Sedangkan shalat menurut istilah adalah ibadah yang terdiri dari perbuatan dan ucapan tertentu yang dimulai dengan takbir dan diakhiri dengan salam. ${ }^{3}$ Dalam melakukan shalat berarti beribadah kepada Allah menurut syarat-syarat yang telah ditentukan.

Menurut Sayyid Sabiq shalat ialah suatu ibadah yang terdiri dari perkataan-perkataan dan perbuatan-perbuatan tertentu yang dimulai dengan takbir bagi Allah SWT dan diakhiri dengan memberi salam. ${ }^{4}$ Perkataan tersebut berupa bacaan-bacaan al-Qur"an, takbir, tasbih, dan doa. Sedangkan perbuatan yang dimaksud berupa gerakan-gerakan dalam shalat misalnya berdiri, ruku", sujud, duduk, dan gerakan-gerakan lain yang dilakukan dalam shalat. Dalam kitab Fathul Qarib diterangkan bahwa shalat yang artimya yaitu: "pengertian shalat menurut bahasa ialah berdoa (memohon), sedangkan menurut pengertian syara" sebagaimana kata Imam Rafi"i, shalat ialah: ucapan-ucapan dan perbuatan-perbuatan yang dimulai dengan takbir dan ditutup dengan salam disertai beberapa syarat yang sudah ditentukan." 5

Shalat adalah sistem ibadah yang tersusun dari beberapa perkataan dan perbuatan yang dimulai dengan takbiratul ihram dan diakhiri dengan salam, didalamnya terdapat doadoa yang mulia serta berdasar atas syarat-syarat dan rukun-rukun tertentu.

Kata jamaah diambil dari kata al-ijtima" yang berarti kumpul. 6 Jamaah berarti sejumlah orang yang dikumpulkan oleh satu tujuan. Shalat jamaah adalah shalat yang dikerjakan secara bersama-sama, sedikitnya dua orang, yaitu yang satu sebagai imam dan yang satu lagi sebagai makmum. ${ }^{7}$ Berarti dalam shalat berjamaah ada sebuah ketergantungan shalat makmum kepada shalat imam berdasarkan syarat-syarat tertentu. Shalat berjamaah adalah beberapa perkataan dan perbuatan yang dimulai dengan takbir dan diakhiri dengan salam, dengan maksud untuk beribadah kepada Allah, menurut syarat-syarat yang sudah ditentukan dan pelaksanaannya dilakukan secara bersama-sama, salah seorang di antaranya sebagai imam dan yang lainnya sebagai makmum.

\footnotetext{
${ }^{1}$ Abdul Aziz Muhammad Azzam dan Abdul Wahhab Sayyed Hawwas, Fiqih ibadah, terj. Kamran As'at Irsyady, dkk, (jakarta: Amzah, 2010). H145.

2 Khairunnas Rajab, psikologi ibadah, ( jakarta: Amzah, 2011), 91.

${ }^{3}$ Hasbiyallah fiqh dan ushul fiqh, ( bandung: PT Remaja Rosdakarya, 2013), 175.

${ }^{4}$ Sayyid sabiq, fiqih sunnah 1, terj. Mahydin Syaf, ( Bandung: PT Alma'arif, 1973), 11.

5 Muhammad bin qosim as-syafi'i, fathul qorib, ( surabaya: imarotullah, t.t), 11.

${ }^{6}$ Mahir Manshur Abdurraziq, Mukjizat Shalat Berjama"ah, terj. Abdul Majid Alimin, (Yogyakarta: Mitra Pustaka, 2007), 66.

${ }^{7}$ Ibnu Rif"ah Ash-shilawy, Panduan Lengkap Ibadah Shalat, (Yogyakarta: Citra Risalah, 2009), 122.
} 
Maka dari itu di pondok pesantren fatahillah dianjurkan untuk sholat berjamaah lima waktu baik untuk perempuan maupun laki-laki guna agar terbiasa disiplin waktu dikarenakan menurunnya kesadaran sebagian santri untuk sholat berjamaah pada waktu shubuh, dzuhur, dan ashar maka dari itu saya sebagai peneliti sangat menginginkan agar meningkatnya kembali kesadaran dan pemahaman santri dalam shalat berjamaah serta terbiasa seperti sebelumnya.

\section{METODE}

Metode kegiatan ini dilakukan dengan cara wawancara, observasi kepada pimpinan pondok dan dewan santri pondok pesantren fatahillah dengan harapan mendapatkan data tentang sejauh mana pemahaman serta kesadaran santri terhadap sholat berjamaah. Kemudian penulis melakukan kegiatan sosialisasi guna melakukan tindakan berupa treatment kedisiplinan pondok.

\section{HASIL DAN PEMBAHASAN}

\section{A. Hasil Kegiatan}

Dalam kegiatan ini, penulis mengambil lokasi di pondok pesantren fatahillah jalan terusan kapten halim blok sawah lega desa pasawahan anyar Rt 08. Rw 11 kecamatan pasawahan kabupaten purwakarta.

Adapun hasil dari penelitian yang saya lakukan dengan mewawancarai sumber dewan santri mengenai pemahaman santri terhadap solat berjamaah, peneliti mendapatkan data bahwasannya kurangnya pemahaman santri sehingga terjadi penurunan kesadaran santri terhadap ibadah shalat berjamaah. Dan mewawancarai dewan santri yang sama dengan bertanya apa faktor penyebab utama terjadinya penurunan kesadaran santri terhadap sholat berjamaah jawabnya faktor utamanya yaitu kurangnya waktu istarahat santri dikarnakan adanya program English Course, dan faktor penghambat lainnya yaitu fasilitas kamar mandi yang kurang sehingga para santri harus ngantri untuk mengambil wudhu. Dan di wawancara terakhir yaitu bagaimana cara dewan santri dalam menangani hal ini, agar santri terbiasa kembali untuk melakukan sholat berjamaah, jawaban yang di berikan dewan santri yaitu akan di adakan hukuman bagi santri yang tidak melakukan sholat berjamaah, hukumannya berupa uang dendaan. selain itu dewan santri melakukan tindakan dengan memperketat lagi dalam segi pemantauan serta pendekatan terhadap masing-masing santri oleh jajaran pihak Pengurus dan Dewan santri, yang mana pendekatan ini lebih ke mengajak sama-sama melaksanakan sholat berjamaah bersama. ${ }^{8}$

Kesimpulan dari hasil wawancara kepada dewan santri bahwasannya kurangnya pemahaman santri terhadap sholat berjamaah dengan bukti terjadinya penurunan kesadaran santri terhadap sholat berjamaah dan yang menjadi faktor penyebabnya yaitu kurangnya waktu istirahat dikarnakan program pembelajaran yang padat dan fasilitas kamar mandi yang kurang sehingga menghambat santri dalam pengambilan wudhu dan tindakan yang lakukan oleh dewan santri yaitu dengan di adakannya hukuman berupa dendaan uang bagi santri yang tidak melakukan sholat berjamaah serta melakukan pendekatan terhadap masing - masing santri serta mengadakan sosialisasi tentang nilai penting sholat berjamaah.

\footnotetext{
${ }^{8}$ Wawancara Dewan Santri ( ustadzah Dita Nurrozyah)
} 


\section{B. Pembahasan}

Tingkat Pemahaman santri terhadap sholat berjamaah sangat penting agar para santri memiliki kesadaran sendiri untuk sholat berjamaah di samping itu dengan padatnya jadwal pembelajaran membuat santri merasa kewalahan dikarenakan kurangnya waktu istirahat di siang hari sehingga hal ini berpengaruh terhadap penurunan kesadaran santri untuk mengikuti sholat berjamaah, sedangkan sholat berjamaah ini penting bagi kita selain akan mendapatkan pahala 27 kali lipat dari pada solat sendiri, dan dijauhkan dari siksa neraka juga dapat berpengaruh terhadap pribadi santri dalam banyak hal salah satunya yaitu membuat santri lebih disiplin waktu.

Shalat adalah sistem ibadah yang tersusun dari beberapa perkataan dan perbuatan yang dimulai dengan takbiratul ihram dan diakhiri dengan salam, didalamnya terdapat doadoa yang mulia serta berdasar atas syarat-syarat dan rukun-rukun tertentu.

Kata jamaah diambil dari kata al-ijtima "yang berarti kumpul. ${ }^{9}$ Jamaah berarti sejumlah orang yang dikumpulkan oleh satu tujuan. Shalat jamaah adalah shalat yang dikerjakan secara bersama-sama, sedikitnya dua orang, yaitu yang satu sebagai imam dan yang satu lagi sebagai makmum. ${ }^{10}$ Berarti dalam shalat berjamaah ada sebuah ketergantungan shalat makmum kepada shalat imam berdasarkan syarat-syarat tertentu. Shalat berjamaah adalah beberapa perkataan dan perbuatan yang dimulai dengan takbir dan diakhiri dengan salam, dengan maksud untuk beribadah kepada Allah, menurut syarat-syarat yang sudah ditentukan dan pelaksanaannya dilakukan secara bersama-sama, salah seorang di antaranya sebagai imam dan yang lainnya sebagai makmum.

Mengenai pemahaman santri terhadap Nilai penting sholat berjamaah, menurut Ustadzah Dita Nurrozyah bahwasannya pemahaman santri terhadap sholat berjamaah itu kurang sehingga terjadi penurunan kesadaran santri terhadap ibadah shalat berjamaah. Dan menurutnya juga ini terjadi karena faktor kurangnya waktu istirahat dikarnakan program pembelajaran yang padat dan fasilitas kamar mandi yang kurang sehingga menghambat santri dalam pengambilan wudhu dan tindakan yang lakukan oleh dewan santri yaitu dengan di adakannya hukuman berupa dendaan uang bagi santri yang tidak melakukan sholat berjamaah.

Penulis melakukan tindakan lapangan yaitu dengan cara melakukan sosialisasi dan treatment tentang pemahaman nilai penting sholat berjamaah terhadap santri guna meningkatkan kembali kesadaran santri untuk melaksanakan sholat secara berjamaah.

kesimpulan dari pembahasan di atas Tingkat Pemahaman santri terhadap sholat berjamaah sangat penting agar para santri memiliki kesadaran sendiri untuk sholat berjamaah.

Adapun menurut Narasumber yang peneliti wawancarai di pondok pesantren fatahillah ini terdapat penurunan kesadaran untuk sholat berjamaah dengan faktor penyebab padatnya jadwal pembelajaran, kurangnya waktu istirahat dan kurangnya fasilitas kamar mandi, dan solusi terkait permasalahan tersebut maka peneliti melakukan sosialisasi terhadap santri dengan memberikan pemahaman terkait pentingnya solat berjamaah.

\footnotetext{
${ }^{9}$ Mahir Manshur Abdurraziq, Mukjizat Shalat Berjama"ah, terj. Abdul Majid Alimin, (Yogyakarta: Mitra Pustaka, 200766.

${ }^{10}$ Ibnu Rif"ah Ash-shilawy, Panduan Lengkap Ibadah Shalat, (Yogyakarta: Citra Risalah, 2009), 122.
} 


\section{KESIMPULAN}

Ibadah ialah rangkaian yang dilakukan manusia dalam rangka pengabdian, kepatuhan kepada Allah. Dengan adanya program english Course, dari hasil pengamatan penulis telah terjadi penurunan kesadaran santri dalam sholat berjamaah. Bertolak dari hal tersebut, penulis melakukan penelitian di ponpes fatahillah Desa pasawahan anyar. Bertujuan untuk mengetahui Nilai penting sholat Berjamaah, mengetahui penyebab penurunan dan peningkatan kesadaran santri terhadap solat berjamaah. Peningkatan kesadaran santri dalam beribadah ini penting sebab hal tersebut merupakan tolak ukur keberhasilan santri baik dalam hal ibadah dan kegiatan lainnya. Metode yang digunakan penulis adalah kualitatif deskriptif dengan cara observasi dan wawancara. Hasil peroleh dari penelitian yang penulis lakukan yaitu diadakannya sosialisasi paedah sholat berjamaah yaitu pahalanya $27 x$ lipat dari pada sholat sendiri maka santri mampu mengetahui pentingnya sholat berjamaah. Dapat mengetahui faktor penyebab penurunan kesadaran santri terhadap sholat berjamaah yaitu padatnya jadwal pembelajaran dan kurangnya kedisiplinan. Peningkatan kesadaran sholat berjamaah terlihat normal setelah diadakannya sosialisasi pentingnya sholat berjamaah.

\section{DAFTAR PUSTAKA}

Santri Kateglo" kateglo.com. diakses tanggal 3 agustus 2017 from https://id.m.wikipedia.org/wiki/santri

Effendi, M. R., \& Nurpratiwi, S. (2021). H Hubungan Keberagamaan dan Perilaku Altruistik Mahasiswa. al-Afkar, Journal For Islamic Studies, 4(1).

Feri Efendi, Makhfudli. 2009. Teori dan peraktik dalam keperawatan. Jakarta: Salemba Medika. Abdul Aziz Muhammad Azzam dan Abdul Wahhab Sayyed Hawwas, 2010. Fiqih ibadah, terj.

Kamran As'at Irsyady, dkk. Jakarta:Amzah.

Khairunnas Rajab, 2011. psikologi ibadah. Jakarta: Amzah.

Hasbiyallah, 2013, fiqh dan ushul fiqh. Bandung: PT Remaja Rosdakarya.

Sayyid sabiq, 1973. fiqih sunnah 1, terj. Mahydin Syaf. Bandung: PT Alma'arif.

Mahir Manshur Abdurraziq, 2007. Mukjizat Shalat Berjama"ah, terj. Abdul Majid Alimin.

Yogyakarta: Mitra Pustaka.

Ibnu Rif"ah Ash-shilawy, 2009. Panduan Lengkap Ibadah Shalat. Yogyakarta: Citra Risalah. 